\title{
Effect of Straw Throwing Method and Some Operational Parameters on the Performance of a Small Rectangular Baler
}

\author{
Affan O. Hussein \\ Department of Plant Protection, Khabat Technical Institute, Erbil Polytechnic University, Erbil, Kurdistan Region, Iraq
}

\section{${ }^{*}$ Corresponding author: \\ Affan O. Hussein, \\ Department of Plant \\ Protection, Khabat Technical Institute, Erbil Polytechnic \\ University, Erbil, Kurdistan \\ Region, Iraq. \\ E-mail: affan@epu.edu.iq}

Received: 12 April 2020

Accepted: 19 July 2020

Published: 30 December 2020

DOI

10.25156/ptj.v10n2y2020.pp21-26

\section{A B S T R A C T}

The experiment was carried out on a private farm in Karak village in 2017 to study the effects of the method of throwing the straw behind the combine harvester and some operational factors on the performance of a small rectangular baler. The field was planted with wheat (Triticum spp.) and barley (Hordeum vulgare). A small rectangular baler type (Ćicoria 454), Italian made was used to pick up and bale the straws, which were thrown as heaps and windrows in the field. The results obtained showed that picking up the straw as windrows improved the baler's performance over the heaps in terms of number of mechanical units stops, time require for baling, fuel consumption, baler's throughput capacity, and baler's throughput efficiency, on the other hand, the forward speed also affected the baler's performance when the straw was thrown as windrows; By increasing the forward speed, the slippage percentage increased but the fuel consumption, baler's throughput efficiency, and baler's throughput capacity decreased.

Keywords: Barley straw; Heaps; Rectangular baler; Wheat straw; Windrows

\section{INTRODUCTION}

Straw is an agricultural by-product consisting of the dry stalks of cereal plants such as wheat, barley, oats, rye, and rice after the grain and chaff been removed. The grain ratio to the straw is about 1:1.5-1:2.0 (Chandrasekaran et al., 2010). Straw has many uses, including livestockfodder, livestock bedding, paper industries, and fuels (Vink, 2015). In Kurdistan region the main usage of straw is as livestock fodder. Annually, there are about 0.75 million ha cultivated area with cereal crops mainly wheat and barley (Ministry of Planning, 2017); this resulting in nearly 1.5 million tons of straw. Straws are always thrown behind the combine harvester in three forms: (1) Directly on the ground as windrows (STW), (2) thrown as heaps (STH) on the ground by a gathering mechanism equipped on to the harvester and it is pre-adjustable to a desired weight, which is the most common method used by farmers in the Kurdistan region of Iraq, and (3) cutting and spreading the straws in the field in one operation by the harvester for conservative agriculture. The bulk density of loose straws is very low, which make their handling and transport operations difficult and costly as well as wide space for storage needed. It should be transformed to regular and dense form to facilitate transporting and storing (Gummert et al., 2020).
Straw is generally gathered and stored in bales. The bale is a bundle of straw tightly bound with twine wire or string. Straw bales may be square, rectangular, or round and can be small or large depending on the type of baler (Srivastava et al., 2006). There are some factors affecting the pickup performance of the baler such as forward speed and crop density (Alnima, 1990). The method of picking up the straw mechanically affects the quality and the quantity of the work (Afify et al., 2002). The forward speed of the baling operation has a significant effect on the bale quality. Furthermore, high speed causes machine wheels slippage, which leads to power losses (Morad et al., 2002). The slippage percentage is an indicator of the tractor and baler work quality. Limiting or reducing the slippage percentage leads to a good, economic, and effortless work (Al-Auobi and Taha, 2009). Fuel consumption of the tractor affects with increasing of the forward speed according to the equipped machine. Economically, fuel costs represent at least $16-45 \%$ of the hourly costs of an agricultural tractor, and this represents the largest share of the total cost of an hour of machine work (Farias et al., 2017).

According to our observation in the field, there was misusing of the balers for straw baling; therefore, the main objective to conduct this research was to find the 
best combination of parameters for the straw baling which leads to the best performance of the baler.

\section{MATERIALS AND METHODS}

The work was carried out in 2017 in a private field in Karak village - Ainkawa district - Erbil City - Kurdistan Region Iraq which was planted with wheat (Triticum spp.) and barley (Hordeum vulgare). The field distinguished with a high leveled land with few natural girders. Crops were harvested at $10 \mathrm{~cm}$ above the ground by a combine harvester (John Deere 1980 model 6620 American made with a cutting width of $488 \mathrm{~cm}$ ) on May 15, 2017, and June 1, 2017, for barley and wheat, respectively. They were harvested when the grain moisture content reached about $16 \%$. The moisture content was determined according to the ASABE Standard S358.2, (2008).

Two areas of 1.2 ha selected for each crop type. The first 0.2 ha for throwing the straw behind the combine harvester as heaps form on the ground (STH) and the second 1 ha for throwing the straw as windrow (STW) to study their effects on the performance of a small rectangular baler drawn by the tractor. Both experiments were conducted using a small rectangular baler type (Ćicoria 454), Italian made with a working width of $140 \mathrm{~cm}$ and baling chamber of $35 \mathrm{~cm} \times$ $47 \mathrm{~cm}$, the bale length was adjusted to $90 \mathrm{~cm}$, the baler is shown in Figure 1. The baler was drawn by a multipurpose Massey Fergusson tractor (MF 275 American made, pneumatic, two wheel drives, our cylinder, diesel engine, $75 \mathrm{HP}$ at $2200 \mathrm{rpm}$, and P.T.O single speed of $540 \mathrm{rpm}$ at 1790 engine $\mathrm{rpm}$ ). Traveling distance of the tractor with the baler was limited to $100 \mathrm{~m}$ long by putting indicating poles at the beginning and the end of the distance.

Two experiments were conducted for straw baling. The first one was for comparing between straw picking up as heaps and picking up as windrows by a baler at a forward speed of $1.12 \mathrm{~m} / \mathrm{s}$ according to the ASABE standard D497.6, (JUN2009) for both Barley straw (BS) and Wheat straw (WS). The second experiment was applied for comparing different forward speeds $\mathrm{S}_{1}=1.12, \mathrm{~S}_{2}=1.4, \mathrm{~S}_{3}=1.69$,

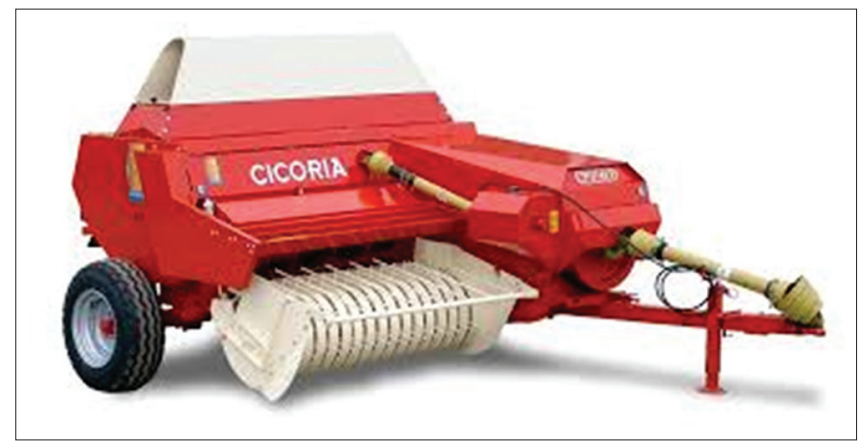

Figure 1: Small rectangular baler type (Ćicoria 454)
$\mathrm{S}_{4}=1.97$, and $\mathrm{S}_{5}=2.24 \mathrm{~m} / \mathrm{s}$ for selecting the ideal forward speed for wheat and BS baling as windrows.

The mechanical units traveled $10 \mathrm{~m}$ before reaching the guide poles toward the experimental lines to take its stability and desired speed for each treatment. The traveling time for the determined distance was recorded by a digital stopwatch for traveling without load and later with a load to calculate the slippage percentage of the mechanical units.

Evaluating the baler's performance done by considering the following indicators:

1) Stopping numbers of mechanical units measured by normal counting.

2) The baling rate was calculated according to the equation formed by Srivastava et al. (2006).

$$
M_{f}=\frac{d_{c} * w_{c} * \delta_{s} * \rho_{c} * \omega_{c}}{60}
$$

Where: $M_{f}=$ Baling rate or material feed rate, $(\mathrm{kg} / \mathrm{s})$, $d_{c}=$ Depth of the bale chamber, $(\mathrm{m}), w_{c}=$ Width of the bale chamber, $(\mathrm{m}), \delta_{s}=$ Thickness of each compressed hay slice, (m), $\rho_{c}=$ Compressed density of hay in the bale, $\left(\mathrm{kg} / \mathrm{m}^{3}\right)$, and $\omega_{c}=$ Crank speed, (rpm).

3) Slippage percentage, which was calculated according to the equation formed by Al-Banna, (1990) as follow:

$$
\text { S.P }=\frac{V T-V P}{V T} \times 100
$$

Where S.P = Slippage percentage (\%). VT= Theoretical speed (without load) $\mathrm{m} / \mathrm{s}$. VP= Practical speed (with load) $\mathrm{m} / \mathrm{s}$.

4) Fuel consumption, which was determined using the volumetric method by refilling the fuel tank with a graduated cylinder (Hunt, 2001), the fuel consumption calculated according to the equation suggested by (Jasim and Jebur, 2015) as follow:

$$
\text { F.C. }=\frac{q . d \times 10000}{B . p \times s \times 1000}
$$

Where F.C. $=$ Fuel consumption $(\mathrm{L} / \mathrm{ha}) \cdot q \cdot d=$ Fuel consumed in one round $(\mathrm{ml}) . B \cdot p=$ Actual working width $(\mathrm{m})$. and $S=$ Distance of one round (m).

5) Throughput efficiency, which was used to describe machines that handle or process a product, such as grain augers, balers, forage harvesters, and combines instead of field efficiency. The throughput efficiency was determined according to the equation formed by Field and John (2007) as follows.

$$
T E=\frac{E T C}{T T C} \times 100
$$


Where TE $=$ Throughput efficiency $(\%)$. ETC $=$ effective throughput capacity (ton/h). TTC $=$ theoretical throughput capacity (ton/h).

Theoretical throughput capacity was calculated by measuring average time of producing one bale under standard conditions (without losses); then, the unit was converted from bale/second to ton/h after multiplying it by the average one bale weight. Effective throughput capacity was calculated by multiplying the bale weight by the actual number of produced bales in $1 \mathrm{~h}$ and expressed in ton/h (Al-Auobi and Taha, 2009).

Statistically, the experiments were carried out by applying the randomized complete block design (RCBD) with four replicates for each treatment. Each line considered as a block and replicate, 24 lines were specified for WS and 24 lines for BS. For each type of straw four lines specified for heap form and 20 lines for windrow form. The data were analyzed using the SAS (2002) program according to the experimental design, Duncan's multiple range tests and T-test applied to compare between the means at $(P \leq 0.01)$ and $(P \leq 0.05)$.

\section{RESULTS AND DISCUSSION}

\section{Experiment 1}

Table 1 shows the effect of straw throwing methods on the mechanical units and baler's performance and bale characteristics for wheat and BS. Significant differences $(P \leq 0.01)$ were found in the stopping number of the mechanical units between STH and STW, the average stopping numbers were 100 and 3.5 stop/ha, respectively. This leads to an extension in the operating life of the mechanical parts as well as reducing the total working time as it is shown in the table, also reducing the chances for mechanical damages of the tractor especially the clutch due to the frequent stops. The average time spent for baling wheat and BSs was 01:14:30 and $00: 59 \mathrm{~h} / \mathrm{ha}$ for STH and STW, respectively. Fuel consumption was significantly higher for STH compared with STW, the averages were 4.9 and $3.7 \mathrm{~L} / \mathrm{h}$, respectively, the reason for increasing the fuel consumption is the increasing in the number of stopping when using STH method which requires more working time to complete the specified area. In general, the fuel consumption was within the acceptable range that determined by Grisso et al. (2010). The baler throughput capacity also was significantly less when using STH method compared with STW method and the averages were 1.294 and 1.372 tons $/ \mathrm{h}$, respectively. This increase is due to the continually picking up straw from the ground when it is thrown as windrows. The average of baler throughput efficiency of the baler for straw picking up was $70 \%$ and $81 \%$ for STH and STW, respectively; in addition they showed significant differences between both methods. This difference was occurred because of the large number of stops during the work; therefore, increasing the time spent for a specific area when the straw was in the heaps forms and thus reduces the value of throughput efficiency.

The average number of bales produced for both methods STH and STW did not show any differences as it is shown in the table. There were significant differences in the type of straw baled. The mean number of WS bales exceeded the mean number of BS bales for STH and STW methods. For both methods, it was 116 and 104 bales/ha for wheat and 120 and 114 bales/ha for barley, respectively. No significant differences appeared in the average weight of the bale for both methods, while significant differences appeared in the mean weight of one WS bale and BS bale and it was 12.5 and $10.9 \mathrm{~kg}$, respectively. The reason for these differences attributed to the differences in the stem diameter and thickness of wheat and BS. The BS stem is lighter than the WS stem. For the same reason, the density of WS bale significantly increased over the density of BS bales and the means were 83.3 and $72.7 \mathrm{~kg} / \mathrm{m}^{3}$, respectively.

Table 1: Effect of straw throwing methods on the mechanical units, baler performance, and bales characteristics for wheat and barley

\begin{tabular}{|c|c|c|c|c|c|c|}
\hline \multirow[t]{3}{*}{ Parameters } & \multicolumn{6}{|c|}{ Straw throwing as } \\
\hline & \multicolumn{3}{|c|}{ Heaps (STH) } & \multicolumn{3}{|c|}{ Windrows (STW) } \\
\hline & WS & BS & Average & WS & BS & Average \\
\hline Number stops of mechanical units per hectare & $108^{\mathrm{a}}$ & $92^{b}$ & $100^{c}$ & $4^{d}$ & $3^{d}$ & $3.5^{\mathrm{d}}$ \\
\hline Time required for baling, (h/ha) & $01: 15^{a}$ & $01: 14^{\mathrm{a}}$ & $01: 14: 3^{a}$ & $00: 59^{b}$ & $00: 59^{b}$ & $00: 59^{b}$ \\
\hline Fuel consumption (L/ha) & $4.9^{a}$ & $4.9^{a}$ & $4.9^{\mathrm{a}}$ & $3.7^{\mathrm{b}}$ & $3.7^{\mathrm{b}}$ & $3.7^{\mathrm{b}}$ \\
\hline Slippage percentage (\%) & - & - & - & $3.9^{\mathrm{a}}$ & $3.8^{\mathrm{a}}$ & $3.85^{\mathrm{a}}$ \\
\hline Throughput capacity of the baler (ton/h) & $1.450^{\mathrm{a}}$ & $1.137^{\mathrm{d}}$ & $1.294^{c}$ & $1.5^{\mathrm{a}}$ & $1.243^{c}$ & $1.372^{\mathrm{b}}$ \\
\hline Baler field efficiency (\%) & $71^{b}$ & $69^{b}$ & $70^{\mathrm{b}}$ & $82^{a}$ & $80^{a}$ & $81^{\mathrm{a}}$ \\
\hline Number of bale produced (bale/ha) & $116^{\mathrm{ab}}$ & $104^{c}$ & $110^{\mathrm{bc}}$ & $120^{\mathrm{a}}$ & $114^{b}$ & $117^{\mathrm{ab}}$ \\
\hline Bale weight $(\mathrm{kg})$ & $12.5^{\mathrm{a}}$ & $10.9^{b}$ & $11.7^{\mathrm{ab}}$ & $12.5^{\mathrm{a}}$ & $10.9^{b}$ & $11.7^{\mathrm{ab}}$ \\
\hline Bale bulk density (kg/m) & $83.3^{a}$ & $72.7^{\mathrm{b}}$ & $78^{\mathrm{ab}}$ & $83.3^{a}$ & $72.7^{\mathrm{b}}$ & $78^{\mathrm{ab}}$ \\
\hline Baling rate $(\mathrm{kg} / \mathrm{s})$ & - & - & - & $0.417^{a}$ & $0.364^{b}$ & $0.391^{\mathrm{ab}}$ \\
\hline
\end{tabular}

Different letters within the rows mean significant differences between means under the probability level of $(P<0.05)$ and $(P<0.01)$. WS: Wheat straw, BS: Barley straw 
For the same reason, the baling rate of WS was higher than the BS and it was 0.417 and $0.364 \mathrm{~kg} / \mathrm{s}$, respectively.

\section{Experiment 2}

The effects of the forward speed on the time spent by the baler for baling wheat and BS as windrows in the field are shown in Figure 2. In general, the time spent for straw baling decreased as the forward speed increased for both types of straws. The shortest time was recorded when the forward speed was $2.24 \mathrm{~m} / \mathrm{s}$ and the longest time spent was with the forward speed of $1.12 \mathrm{~m} / \mathrm{s}$. The averaged time was $0: 31$ and $0: 59 \mathrm{~h} / \mathrm{h}$, respectively. The forward speeds did not affect the type of the straw.

Figure 3 shows the effect of the forward speed on the baler's throughput capacity. Increasing the forward speed of the baler gradually from $1.12 \mathrm{~m} / \mathrm{s}$ to $1.4,1.69,1.97$, and $2.24 \mathrm{~m} / \mathrm{s}$ significantly decreased the throughput capacity $1.5,1.5,1.489,1.462$, and 1.422 ton/h for WS, respectively, and $1.243,1.231,1.232,1.211$, and 1.189 ton/h for BS, respectively. This decrement is attributed to the nonsynchronization between the tractor forward speed and the pickup reel fingers of the baler which leads to skipping some straw stems on the ground and losses occur due it. These results agree with the results found by Morad et al. (2002). From the results, there were not any significant differences

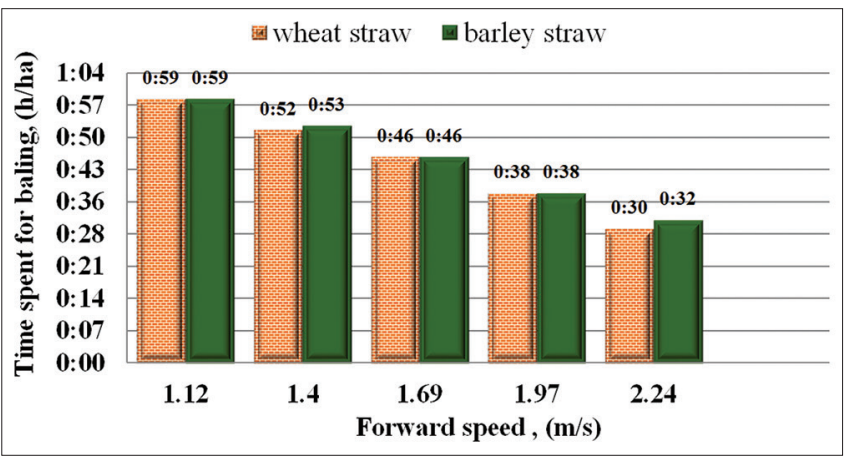

Figure 2: Effects of the forward speed on the time spent by the baler

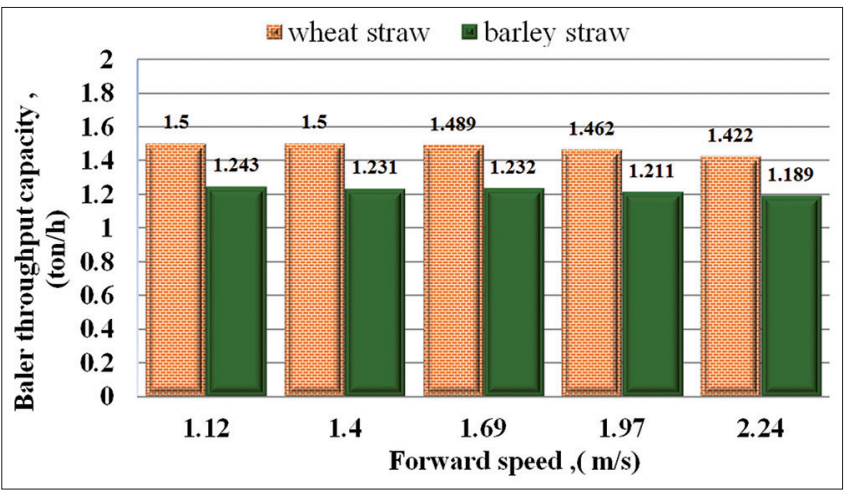

Figure 3: Effect of the forward speed on the baler's throughput capacity between the forward speed of $1.12 \mathrm{~m} / \mathrm{s}$ and $1.69 \mathrm{~m} / \mathrm{s}$ in the baler's throughput capacity. In addition, there were significant differences between WS baler's throughput capacity, and BS baler's throughput capacity. The WS baling throughput capacity increased above the BS baling throughput capacity for all forward speeds. These increments are due to the differences between the thicknesses of the stems of two types of straws. The BS stems are lighter than the WS stems.

The effect of the forward speed of the baler drawn by the tractor on the slippage percentage is shown in Figure 4. The slippage percentage increased gradually with increasing the forward speed. The highest slippage percentage was recorded when the forward speed was $2.24 \mathrm{~m} / \mathrm{s}$ while the lowest slippage percentage was observed with the forward speed of $1.12 \mathrm{~m} / \mathrm{s}$ and the averages were $5.45 \%$ and $3.85 \%$, respectively. The reason of this is due to reducing the chances of tires cohesion with the ground, these results are agreed with results obtained by Al-Auobi and Taha (2009). No significant differences were observed between the WS and $\mathrm{BS}$ for each forward speed on the slippage percentage.

Figure 5 illustrates the effect of the forward speed on the fuel consumption of the tractor and the baler.

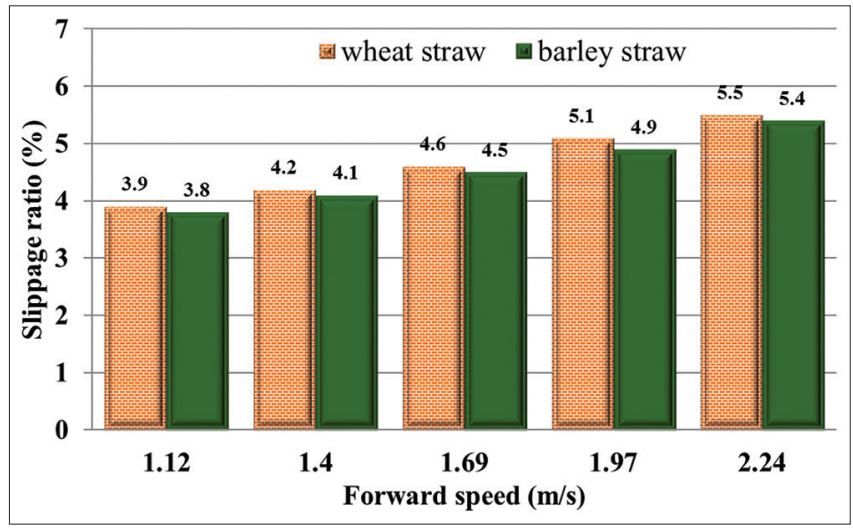

Figure 4: Effect of the forward speed of the baler's on the slippage percentage

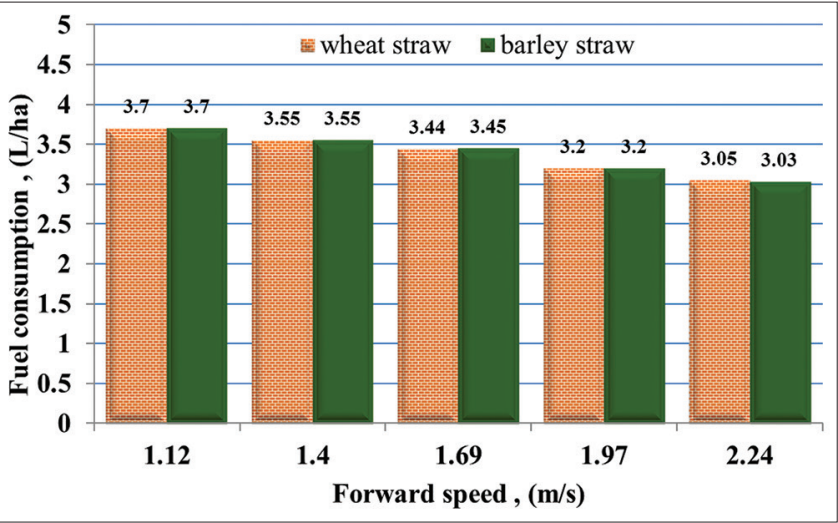

Figure 5: Effect of the forward speed on the fuel consumption of the tractor and the baler 


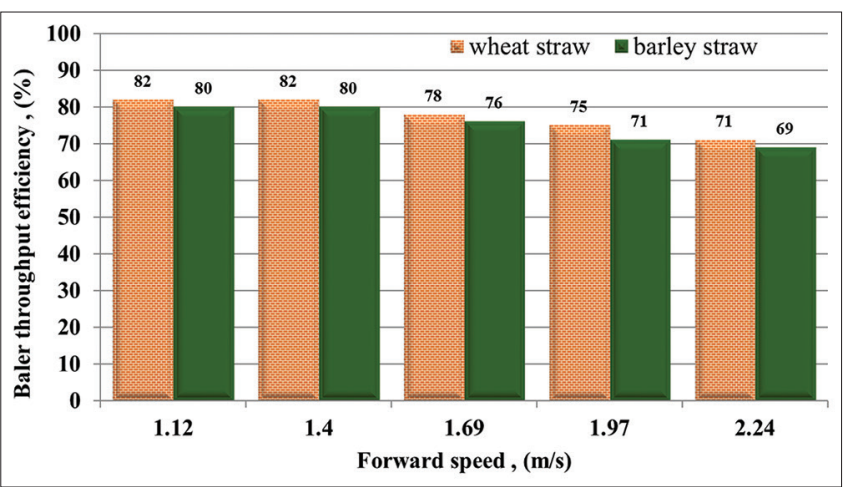

Figure 6: Impact of the forward speed on the baler's field efficiency

Statistically increasing the forward speed did not affect the fuel consumption of baling process. There were mathematically differences between the forward speeds. The highest amount of fuel consumption measured was with the forward speed of $1.12 \mathrm{~m} / \mathrm{s}$ and the lowest fuel consumption was with forward speed of $2.24 \mathrm{~m} / \mathrm{s}$. The reason for this is attributed to the limiting the tractors engine rpm during all baling operations for all treatments which was $1790 \mathrm{rpm}$ to operate the baler in $540 \mathrm{rpm}$. The forward speeds increased by gears. These results disagree with the results obtained by Afify et al. (2002), who found that any increase in the forward speed leads to an increase in the fuel consumption in straw baling operation because they did not limited the engine rpm.

Figure 6 shows the impact of the forward speed on the baler's throughput efficiency. The results showed a gradually decreasing in the baler throughput efficiency by increasing the forward speed from $1.12 \mathrm{~m} / \mathrm{s}$ to $1.4,1.69$, 1.97 , and $2.24 \mathrm{~m} / \mathrm{s}$. The averages of the drop were $81 \%$, $81 \%, 77 \%, 73 \%$, and $70 \%$, respectively. The main reason of baler throughput efficiency dropping is the reduction in the throughput capacity when the forward speed increased. The throughput efficiency depends on the theoretical throughput capacity and effective throughput capacity as a numerator in the equation and usually is lower than theoretical throughput capacity. There were no significant differences in the baler throughput efficiency between the forward speeds $1.12 \mathrm{~m} / \mathrm{s}$ and $1.69 \mathrm{~m} / \mathrm{s}$. These results came in agreement with the results obtained by Morad et al. (2002). The type of the straw did not influence the baler throughput efficiency of the baler for any forward speed.

\section{CONCLUSIONS}

The baler performance was improved when the straw was thrown in the field as windrows form comparing with the heaps form. The forward speed affected the baling process and the baler efficiency. The fuel consumption was lower when the forward speed increased. Therefore, we recommend the farmers to adjust their combines to throw the straw as windrows behind the harvesters to facilitate work of the pickup balers. In addition, selecting the forward speed that is not excessed $1.96 \mathrm{~m} / \mathrm{s}$ will give the best performance of the baler.

\section{REFERENCES}

Afify, M. T., A. H. Bahnasawy, and S. A. Ali. 2002. Effect of Rice Straw Picking up Method on the Performance of a Rectangular Baler. AIC 2002 Meeting CSAE/SCGR Program, Paper No. 02-217, Saskatoon, Saskatchewan.

Al-Auobi, T. H. M and S. Y. Taha. 2009. Effect of baler type and tractor speed on slippage percentage, baler productivity and baler field efficiency. Al-Forat J. Agric. Sci. 1(4): 183-188.

Al-Banna, A. R. 1990. Tillage Equipment. Dar Al-Kutub for Press and Publishing, Mosul University, Iraq.

Alnima, M. J. 1990. Mechanization of Stock Breeding. Dar Al-Kutub for Press and Publishing, Mosul University, Iraq.

ASABE Standard. 2008. S358.2: Moisture Measurement-Forages. ASABE, St. Joseph, Michigan.

ASABE Standard. 2009. D497.6, Agricultural Machinery Management Data. $45^{\text {th }}$ ed. ASABE Standards, St. Joseph, Michigan, USA.

Chandrasekaran, B., K. Annadurai and E. Somasundaram. 2010. A Textbook of Agronomy. New Age International Publishers, New Delhi, India.

Farias, M. S., J. F. Schlosser, P. Linares, J. P. Barbieri, G. M. Negri, L. F. V. Oliveira and I. I. P. Rüdell. 2017. Fuel consumption efficiency of an agricultural tractor equipped with a continuously variable transmission. Ciênc. Rural. 47(6): 1-7. Available from: https://www.pdfs. semanticscholar.org/43f4/2cabb63869e415ea8411867f1206 ba9f2246.pdf?_ga=2.250194566.1283332491.15960427711170248589.1578002783. [Last accessed on 2020 Mar 02].

Field, H. L and B. S. John. 2007. Introduction to Agricultural Engineering Technology. A Problem Solving Approach. $3^{\text {rd }}$ ed. Springer, USA.

Grisso, R. B., J. V. Perumpral, D. Vaughan, G. T. Roberson and R. Pitman. 2010. Predicting Tractor Diesel Fuel Consumption, Publication No. 442-073. Virginia Cooperative Extension, Virginia.

Gummert, M., N. van Hung, P. Chivenge and B. Douthwaite. 2020. Sustainable Rice Straw Management [E-Book]. Springer Open. This Springer Imprint is Published by the Registered company Springer Nature Switzerland AG. Available from: https://www.link.springer.com/content/ pdf/10.1007\%2F978-3-030-32373-8.pdf. [Last accessed on 2020 Mar 21].

Hunt, D. 2001. Farm Power and Machinery Management. $10^{\text {th }}$ ed. A Blackwell Publishing Company, lowa State Press, USA.

Jasim, A. A. and H. A. Jebur. 2015. Impact of primary tillage system on fuel consumption, management and total tractor costs. Iraqi J. Agric. Sci. 46(1): 31-35.

Ministry of Planning Report. 2017. A Survey of Winter Planted Crops in the Kurdistan Region, (Area, Yield, Production, and Cost). Kurdistan Region Government, Ministry of Planning, the Foundation of Statistics of Kurdistan Region.

Morad, M. M., A. E. Hashish, A. F. Abd El-Motalib and A. M. El-Shal. 2002. Effect of some operating parameters on pickup baler 
performance. Misr J. Agric. Eng. 19(1): 136-158.

SAS. 2009. SAS/STAT 9.2 User's Guide, SAS Campus Drive, Cary, North Carolina 27513. $2^{\text {nd }}$ ed. SAS Institute Inc., USA.

Srivastava, A. K., C. E. Goering and R. P. Rothrbach. 2006.
Engineering Principles of Agricultural Machines. $2^{\text {nd }}$ ed. ASABE, St. Joseph, Michigan, USA.

Vink, A. 2015. Crop Residues for Animal Feed. CTA Publications Distribution Service, Netherlands. 